\title{
Rapid cytological diagnosis of basal cell carcinoma of the skin
}

\author{
CHRISTOPHER L. BROWN, MICHAEL R. KLABER, AND \\ M. GILLIAN ROBERTSON
}

From the Departments of Morbid Anatomy and Dermatology, The London Hospital, London E1 1BB, UK

SUMMARY Cytological diagnosis in a series of 153 skin lesions is presented. The diagnosis in each case has been compared with the clinical assessment and, where available, the biopsy result (85 lesions). Of 131 basal cell carcinomas, a cytological diagnosis was possible in 124 while biopsyl failed to identify two of the 73 lesions studied. A correct cytological diagnosis was made in five squamous cell carcinomas and in one malignant melanoma. Basal cell papillomas and solar keratoses were not accurately identified. We thus conclude that with this very simple, rapid, and inexpensive method a clinical diagnosis of basal cell carcinoma is reliably confirmed with advantages for both the clinic and the laboratory.

Basal cell carcinoma is much the commonest skin tumour and can be recognised clinically with a high degree of accuracy. It is a tumour that slowly invades locally and only to a limited extent unless neglected and is therefore amenable to treatment by a variety of simple local ablative measures. A method by which the clinical diagnosis could be quickly confirmed would allow diagnosis and appropriate treatment of many of these lesions to be instituted at the same consultation. The only immediate confirmatory examinations presently available are formal biopsy with rapid frozen section diagnosis or alternatively cytological diagnosis on scrapings. The simplicity of the cytological method from the standpoint of the patient, his physicians, and the laboratory is in its favour. However, its record for reliability will dictate whether a diagnostic method is acceptable. Dudgeon and Patrick in 1927 demonstrated that cytological examination of preparations obtained from fresh tissues yielded an accurate diagnosis in their hands. Strangely little interest appears to have been attracted by their work with only occasional references to the method in the medical literature (Haber, 1954; Urbach et al., 1957; Graham et al., 1961; Selbach and Heisel, 1962; Vilanova et al., 1962).

Cytological diagnosis of skin lesions in Britain today is apparently unknown outside a very few centres, and frozen-section diagnosis also appears not to have been adopted.

Received for publication 29 August 1978
We introduced cytology for the diagnosis of basal cell carcinoma at The London Hospital recently and now record our evaluation of its performance and discuss its clinical application.

\section{Patients and methods}

A total of 81 patients attending the skin department with localised lesions for which a histological diagnosis was required had scrapings for cytological examination taken immediately before a biopsy. In a further 46 patients scrapings alone were taken without a biopsy. In most cases the procedure was undertaken to confirm a clinical diagnosis of basal cell carcinoma. In a few cases a different skin malignancy or pre-malignant condition was suspected or the clinical diagnosis was of a benign lesion, but it was considered desirable to exclude basal cell carcinoma.

The samples for cytology were obtained by firm scraping of the lesion after first removing any surface crust. Usually a scalpel blade was used, alternatively a curette. The material obtained was spread directly onto a glass microscope slide, dried in the air, and subsequently fixed in methanol. Most smears were stained by a short May-Grünwald-Giemsa technique. Alternatively, as a rapid method, they were treated with $0.1 \%$ aqueous toluidine blue for $2 \mathrm{~min}$ utes followed by brief washing in water before routine dehydration, clearing, and mounting. The biopsy tissue was fixed in $10 \%$ formalin in normal saline and processed routinely for histology. The 
cytological and histological diagnoses were made independently but in the light of the clinical diagnosis.

\section{Cytological findings}

The lesions encountered in this study were basal cell carcinoma, squamous carcinoma, malignant melanoma, solar keratosis, basal cell papilloma, and a few other benign lesions.

\section{BASAL CELL CARCINOMA}

In practically all cases plentiful cellular material was obtained, invariably including numerous blood cells and usually numerous polymorphs also. The tumour cells occur dispersed and in small and large clusters (Fig. 1), the latter often having a lobulated outline and showing a cellular pattern similar to that seen in histological sections. The tumour cells are mostly of uniform size and shape, having very little cytoplasm, an oval nucleus with a smooth outline, and evenly dispersed, finely dotted chromatin, sometimes with one or two small distinct nucleoli (Fig. 2). The separated cells show the same cytological features, often more clearly. In some cases the nuclei are flattened, indented, or angulated, and then usually the chromatin is formed into evenly dispersed, coarse clumps (Fig. 3).

Additional features seen in some cases include the presence of mucinous material, more definitely squamous and sometimes keratinised tumour cells, and pigment-containing cells. The mucinous material stains red with both MGG and toluidine blue and appears as irregular smudges scattered over the smear and as discrete blobs within the tumour fragments (Fig. 4). The squamous tumour cells are similar in size to prickle layer cells and typically are uniform in size and occur as irregular clusters or as small nests distinct from the squamous cells of the epidermis (Fig. 5). Small, anucleate, keratinised cells may also be found. Some tumours include cells with a greater quantity of cytoplasm, often drawn out to form a tail. Pigment in the form of small brown granules was only occasionally seen, usually within cells having plentiful cytoplasm. The cells from most tumours are uniform in size and cytological detail with only occasional very large or very small forms. In a few tumours variation in nuclear size and detail was marked throughout the sample, but the form of the cell clusters remained typical of basal cell carcinoma.

SQUAMOUS CARCINOMA

Based on our findings in the four cases of squamous carcinoma we have studied, recognition of malignant squamous cells presents no problem and there should not normally be any difficulty in distinguishing these cases from basal cell carcinoma with squamous differentiation. In our cases squamous carcinoma cells are more varied in size and outline and tend to be larger than the cornifying and undifferentiated

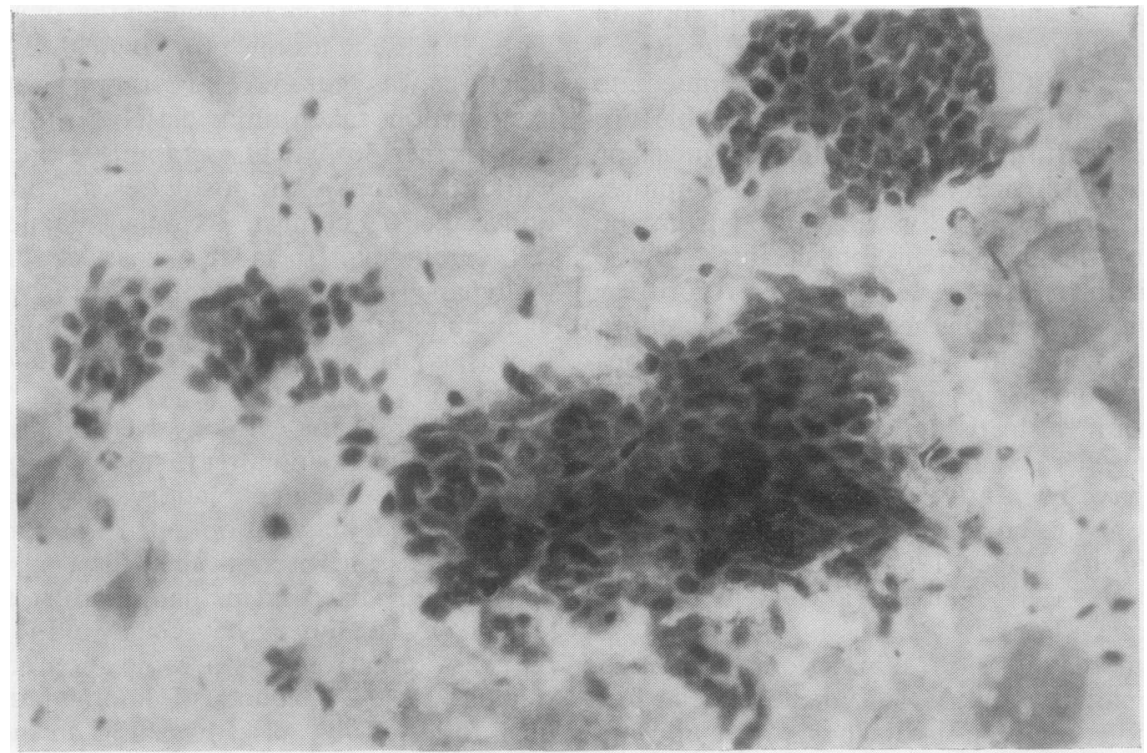

Fig. 1 Characteristic clusters of basal cell carcinoma cells obtained by scraping a lesion. $A$ background of blood and inflammatory cells with some dispersed tumour cells and nuclear strands is usual. Toluidine blue $\times 300$ 


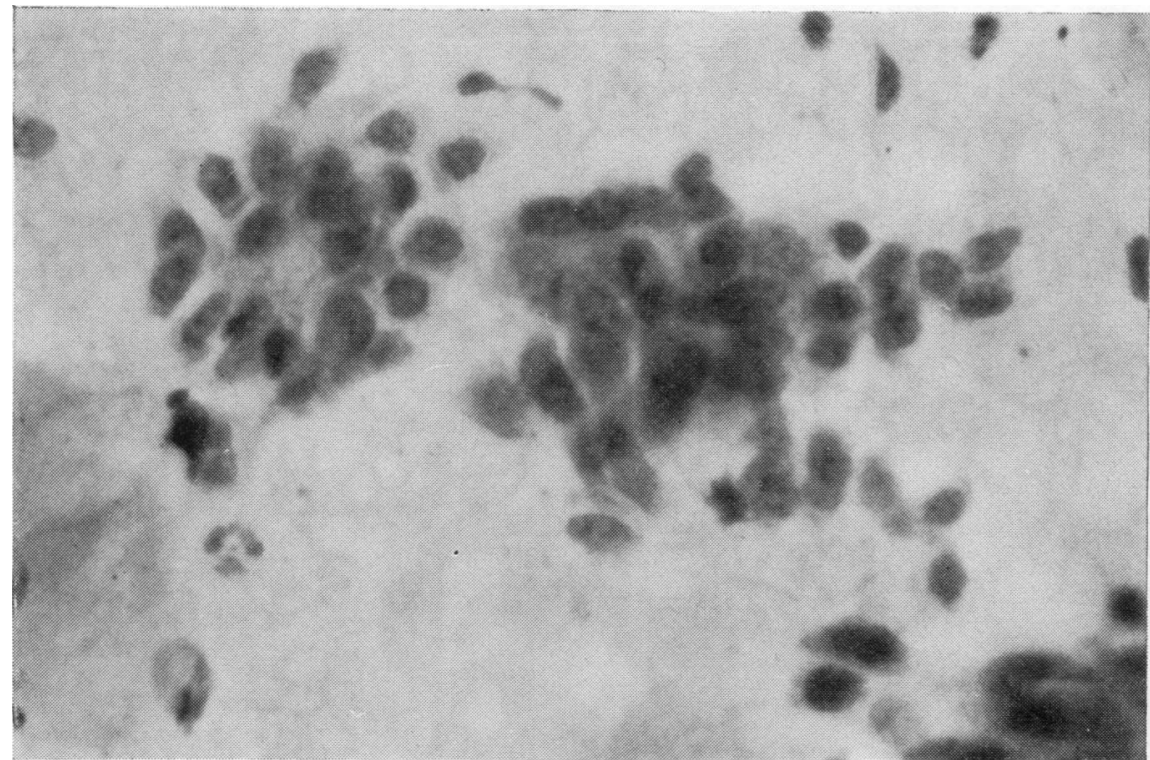

Fig. 2 Part of a cluster of basal cell carcinoma cells. The nuclei are of the more usual type with a smooth outline and evenly distributed fine chromatin. There is only a little ill-defined cytoplasm. Toluidine blue $\times 725$

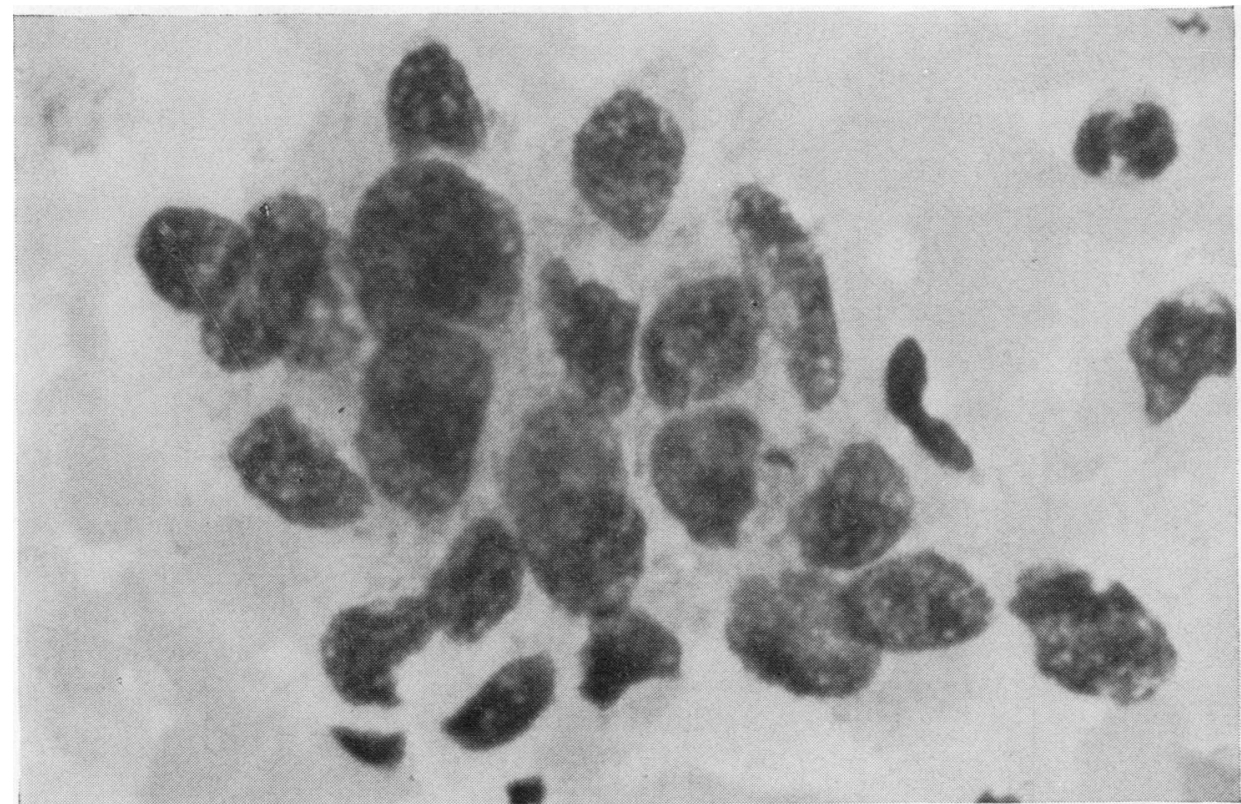

Fig. 3 A small group of the less common type of basal cell carcinoma cells. Their nuclei are of more varied outline with coarse but evenly distributed chromatin. May-Grünwald-Giemsa $\times 900$ 


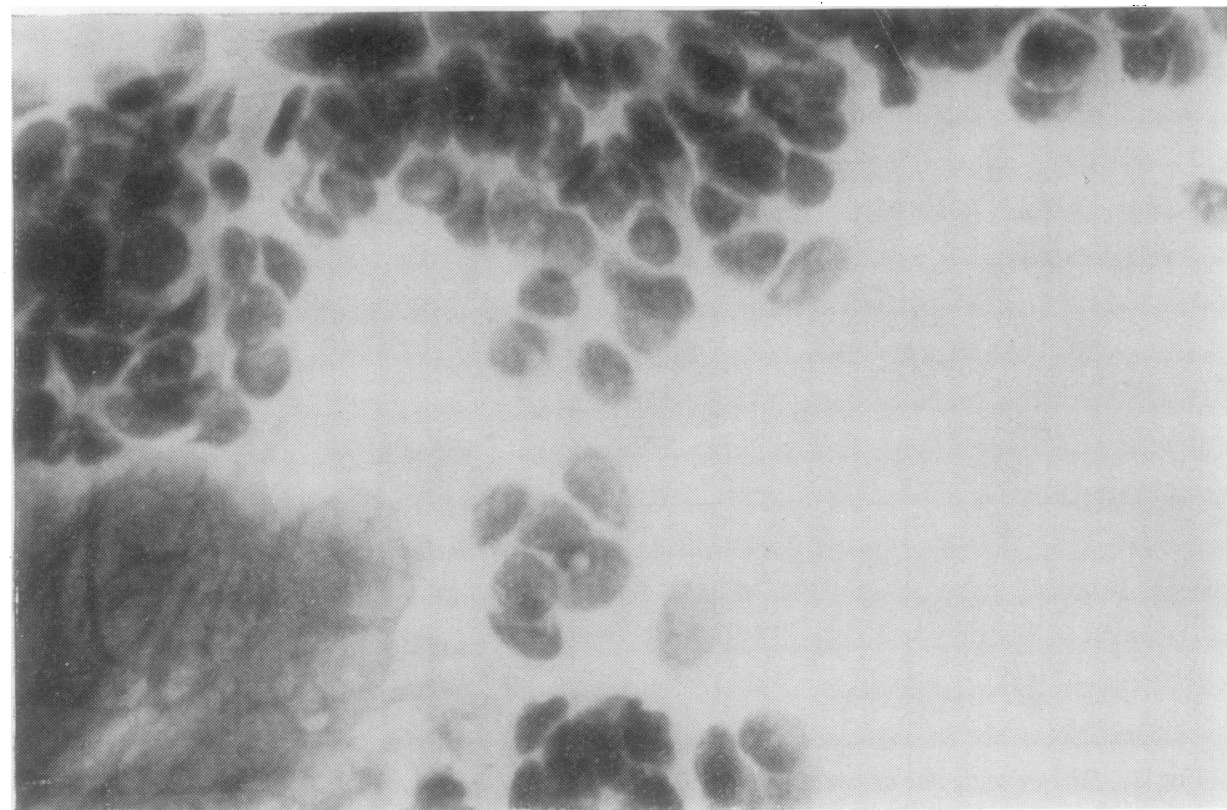

Fig. 4 Tissue fragment from a basal cell carcinoma. There is a blob of mucin in the lower left quadrant of the picture. Toluidine blue $\times 900$

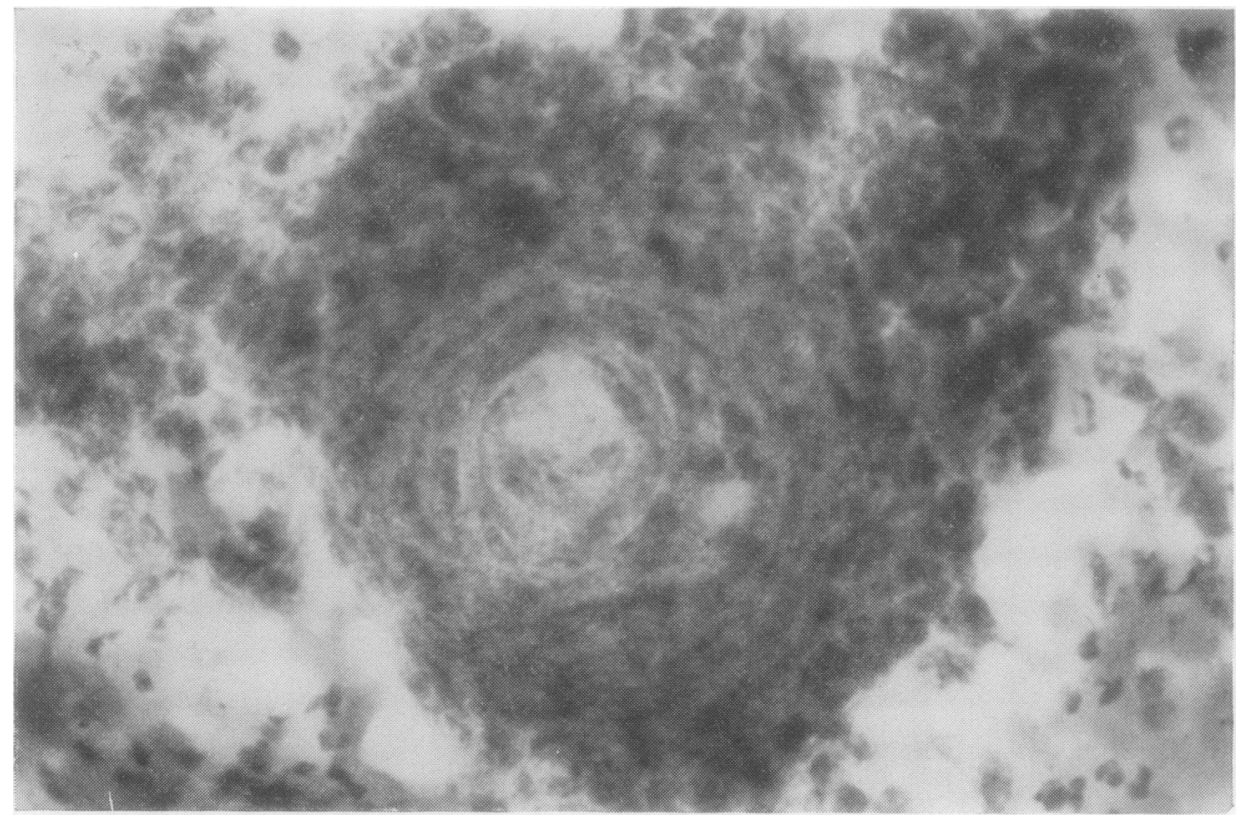

Fig. 5 A fragment from a basal cell carcinoma showing squamous differentiation at its centre. May-Grünwald-Giemsa $\times 425$ 
Table 1 Biopsy series

\begin{tabular}{|c|c|c|c|c|c|c|}
\hline \multirow[t]{2}{*}{ Final diagnosis } & \multirow[t]{2}{*}{ Total } & \multicolumn{2}{|l|}{ Biopsy } & \multicolumn{2}{|c|}{ Cytology } & \multirow[t]{2}{*}{ Cytological misdiagnosis } \\
\hline & & Positive & Negative & Positive & Negative & \\
\hline Basal cell carcinoma & 73 & 71 & $2 *$ & 68 & 4 & $1 \dagger$ \\
\hline Squamous carcinoma & 2 & 2 & 一 & 2 & 一 & - \\
\hline Malignant melanoma & 1 & 1 & 一 & 1 & 一 & - \\
\hline Solar keratosis & 4 & 4 & - & 0 & 4 & - \\
\hline Basal cell papilloma & 5 & 5 & - & 2 & 3 & - \\
\hline
\end{tabular}

* Both cases clinically and cytologically typical.

† Misdiagnosed as squamous carcinoma; see text.

cells in basal cell carcinoma. In well preserved squamous carcinoma cells the nuclear chromatin shows irregular clumping, and nucleoli are often very conspicuous, while some heavily keratinised cells retain a densely staining, pyknotic nucleus.

OTHER CUTANEOUS LESIONS

Normal superficial squamous cells alone were obtained from most of the basal cell papillomas, all of the localised benign scaling eruptions and, rather surprisingly, the solar keratoses. Large clumps of prickle cells allowed a diagnosis of basal cell papilloma in some cases.

\section{Results}

In 12 patients more than one lesion was examined so that a total of 153 lesions are available for analysis from the 127 patients entered in the study. Histological sections were available from 85 lesions, and the results of the cytology are compared with the diagnoses in these cases in Table 1. A diagnosis of squamous carcinoma was suggested from the scrapings in one case of basal cell carcinoma on the basis of finding abnormal cells of squamous type and no clusters or single cells typical of basal cell carcinoma. The biopsy showed very extensive squamous metaplasia and only a minor basal cell component with a morphea pattern. The two basal cell carcinomas that biopsy failed to confirm were typical both clinically and cytologically. The negative cytological results in four cases of basal cell carcinoma were recorded early in the study and can be attributed to inexperience and faulty technique.

The results in the non-biopsy cases are recorded in Table 2. Both negative results recorded in the basal cell carcinoma group were from a man aged 37, from whom scrapings from 14 lesions were taken at a single session. Eleven of the lesions were typical basal cell carcinomas, the three remaining samples showing no evidence of abnormality. He has since developed several further basal cell carcinomas, two of which were at or close to the location of two of the
Table 2 Non-biopsy series

\begin{tabular}{lccccc}
\hline Final diagnosis & \multicolumn{3}{c}{ Cytolog ical diagnosis } & \\
\cline { 2 - 5 } & & Total & $\begin{array}{l}\text { Basal cell } \\
\text { carcinoma }\end{array}$ & $\begin{array}{l}\text { No } \\
\text { abnormality }\end{array}$ & $\begin{array}{l}\text { Squamous } \\
\text { carcinoma }\end{array}$ \\
\hline Basal cell carcinoma & 58 & 56 & 2 & - \\
Squamous carcinoma & 3 & - & -3 & 3 \\
Basal cell papilloma & 3 & - & 3 & - \\
Other benign lesions & 4 & - & 4 & - \\
\hline
\end{tabular}

lesions previously recorded as negative, placing some doubt on the validity of the initial cytology result. The diagnosis in the three squamous carcinomas was made cytologically and in each case was consistent with the clinical findings.

\section{Discussion}

This study was designed to establish the reliability of cytology in confirming a clinical diagnosis of basal cell carcinoma. To this end all the cases seen in the earlier part of the study were subjected to simultaneous biopsy as a check on the accuracy of the cytological diagnosis and to allow a comparison of the positive rate in the two methods. No mistaken diagnosis of basal cell carcinoma was made, and in both cases when cytology gave a false-negative result the cause was attributed to faulty technique in obtaining the specimen, so that, as others have also found (Haber, 1954; Urbach et al., 1957; Graham et al., 1961), once the method is well established the diagnosis of basal cell carcinoma can be made with comparable reliability to that achieved with a biopsy.

The clinical diagnosis of basal cell carcinoma by an experienced observer is very accurate, and it is clearly necessary that any test designed to confirm such a clinical judgement must itself be highly discriminatory. The cytology results in the few lesions clinically misdiagnosed as basal cell carcinoma and also in the other types of lesion seen during the course of this study are therefore important. Five squamous carcinomas and a single case of malignant 
melanoma were correctly identified, and though we were unable to make a definite diagnosis in most cases of basal cell papilloma and solar keratosis, none was misdiagnosed as a basal cell carcinoma.

We have thus amply confirmed the original observations of Dudgeon and Patrick (1927) that accurate recognition of basal cell carcinoma is possible using cytology. The method is subject to a low rate of false-negative recording comparable to that of conventional biopsy diagnosis but not so frequent as to detract from its value. This has been the experience of other observers (Urbach et al., 1957). The only major misinterpretation among the cases of basal cell carcinoma occurred in one case where there was extensive keratinisation, and the subsequent biopsy corrected the cytological diagnosis of squamous carcinoma. Benign skin lesions and solar keratosis, though usually eluding cytological recognition, do not confuse the issue since confronted with a report negative for basal cell carcinoma a decision to proceed to biopsy can be made on clinical grounds. Cytological diagnosis in other malignant skin lesions appears to be reliable with no evidence of misinterpretation as basal cell carcinoma. We are satisfied therefore that cytology can be used with confidence to confirm a clinical diagnosis of basal cell carcinoma, and we are favourably impressed by the many advantages that the method offers.

Basal cell carcinoma is the commonest malignant skin tumour and probably accounts for $1-3 \%$ of patients seen by dermatologists in this country (Rook et al., 1972), many additional cases being seen by radiotherapists and plastic surgeons. The clinical diagnosis is normally confirmed by biopsy which is time-consuming both as a procedure and in waiting time for the result, usually necessitating additional appointments before the patient receives definitive treatment. Most large general hospitals now have a cytology laboratory and would therefore be able to offer immediate cytological diagnosis from scrapings, with a positive result allowing treatment to be instituted at the first consultation. The only alternative method whereby a confirmed diagnosis can be achieved quickly is by use of frozen section histology. By comparison cytology offers many substantial advantages that include, for the patient, who is often elderly and frail, a quick and almost painless procedure that leaves no scar and the prospect of fewer hospital visits; for the clinician, a simple manoeuvre that can be carried out in the consulting room using just a scalpel blade and without need for local anaesthetic; the cytologist gains a modest number of specimens refreshingly different from the routine and with a high probability of being able to give a firm positive diagnosis.
In the course of our investigation a number of additional circumstances favouring the method became apparent. In one patient with 14 lesions, scrapings were quickly obtained and 11 were found to be positive; to biopsy all his lesions would have been a major undertaking. Although this was an exceptional number of lesions, another patient had seven similarly confirmed at a single session. A basal cell carcinoma was confirmed in a third patient with coincidental thrombocytopenia without any complications. Others (Hopp, 1958) have found the method useful in the follow-up of patients treated by radiotherapy. We have found similar advantages in our weekly basal cell carcinoma follow-up clinic; any suspicious lesions can be quickly evaluated and prompt further treatment given if the test is positive, while, if negative, the patient can safely be left for continued observation.

Having established the reliability of the method, a question remains concerning who should take the scrapings. It is clear from our study that most false-negative results are due to inexperience and faulty technique in obtaining the sample. If the cytologist takes the scrapings experience will guarantee good sampling with the added advantage that the patient can wait the few minutes needed for the slide to be read and is available for immediate repeat of the test in the event of a negative result (Canti, 1978, personal communication). Patients with a positive result can, by prior arrangement, be referred for whatever treatment the clinician has indicated.

We thank the physicians of the Department of Dermatology at The London Hospital for access to their patients and for their encouragement. We thank Miss L. Singer for help in the preparation of the manuscript.

\section{References}

Dudgeon, L. S., and Patrick, C. V. (1927). A new method for the rapid microscopical diagnosis of tumours: with an account of 200 cases so examined. British Journal of Surgery, 15, 250-261.

Graham, J. H., Bingul, O., Urbach, F., Burgoon, C. F., Jr., and Helwig, E. B. (1961). Papanicolaou smears and frozen sections on selected cutaneous neoplasms. Journal of the American Medical Association, 178, 380-385.

Haber, H. (1954). Cytodiagnosis in dermatology. British Journal of Dermatology, 66, 79-94.

Hopp, E. S. (1958). Cytologic diagnosis and prognosis in carcinoma of the mouth, pharynx and nasopharynx. Laryngoscope, 68, 1281-1287.

Rook, A., Wilkinson, D. S., and Ebling, F. J. G. (1972). 
Textbook of Dermatology, 2nd edition, p. 73. Blackwell, Oxford.

Selbach, G., and Heisel, E. (1962). The cytological approach to skin disease. Acta Cytologica, 6, 439-442.

Urbach, F., Burke, E. M., and Traenkle, H. L. (1957). Cytodiagnosis of cutaneous malignancy. Archives of Dermatology, 76, 343-350.
Vilanova, X., Aguadé, J. P., and Rueda, L. A. (1962). The cytologic aspects of basal cell carcinoma. Journal of Investigative Dermatology, 39, 123-131.

Requests for reprints to: Dr C. L. Brown, Senior Lecturer in Pathology, Department of Morbid Anatomy, The London Hospital, London, E1 1BB.

\section{Reports and Bulletins prepared by the Association of Clinical Biochemists}

The following reports and bulletins are published by the Association of Clinical Biochemists. They may be obtained from The Publishing Department, British Medical Journal (ACB Technical Bulletins), B.M.A. House, Tavistock Square, London WC1H 9JR. Overseas readers should remit by British Postal or Money Order.

SCIENTIFIC REVIEWS (price $£ 1 \cdot 00 / \$ 2.00$ each)

1 The assessment of thyroid function March 1971 F. V. FLYNN and J. R. HOBBS

2 Renal function tests suitable for clinical practice January 1972 F. L. MTCHELL, N. VEALL, and R. W. E. WATTS

3 Biochemical tests for the assessment of fetoplacenta function May 1975 C. E. WILDE and R. E. OAKEY

4 Test of exocrine pancreatic function March 1977 A. H. GOWENLOCK

TECHNICAL BULLETINS (price $£ 1 \cdot 00 / \$ 2.00$ each)

22 Bilirubin standards and the determination of bilirubin by manual and technicon AutoAnalyzer methods January 1971 BARBARA BILLING, RUTH HASLAM, and N. WALD

23 Interchangeable cells for spectrophotometers and fluorimeters September 1971 s. S. BROWN and A. H. GOWENLOCK

24 Simple tests to detect poisons March 1972 B. w. MRADE et al.

25 Blood gas analysers May 1972 K. DIXON

26 Kits for enzyme activity determination September 1972 S. B. ROSALKI and D. TARLOW

27 Assessment of pumps suitable for incorporation into existing continuous flow analytical systems November 1972 A. FLECK et al.
28 Routine clinical measurements of transferrin in human serum September 1973 K. DIXON

29 Control materials for clinical biochemistry (5th edition) September 1973 J. F. STEVENS

30 Notes on the quality of performance of serum cholesterol assays September 1973 S. S. BROWN

31 Determination of uric acid in blood and in urine July 1974 R. W. E. WATTS

32 A survey of amino acid analysers readily available in the United Kingdom September 1974 J. E. CARLYLE and P. PURKISS

33 Definitions of some words and terms used in automated analysis November 1974 A. FLECK, R. ROBINSON, S. S. BROWN, and J. R. HOBBS

34 Measurement of albumin in the sera of patients January 1975 LINDA SLATER, P. M. CARTER, and J. R. HOBBS

35 Investigation of the validity of temperature correction factors for serum aspartate and alanine transaminases March 1975 S. B. ROSALKI et al.

36 Factors influencing the assay of creatinine November 1975 J. G. H. COOK

37 A survey of enzyme reaction rate analysers readily available in the United Kingdom July 1977 R. A. SAUNDERS and R. F. BURNS

38 Transport of specimens for clinical chemistry analysis November 1977 P. WILDING, J. F. ZILVA, and c. E. WIIDE

39 A scheme for the evaluation of diagnostic kits May 1978 P. H. LLOYD 